\title{
Organizacja procesu zarządzania wierzytelnościami masowymi w bankach
}

\begin{abstract}
Wojciech Kurytek*
Artykut prezentuje, tak kluczowy dla obrony banku przed zbyt duzym ryzykiem kredytowym, proces odzyskiwania wierzytelności masowych. Efektywne prowadzenie dziatań windykacyjnych ma bowiem niezwykle istotny wplyw na obniżanie przez bank wskaźnika udziatu kredytów niepracujacych. Jest to proces dtugi i żmudny oraz wymagajacy specjalistycznej wiedzy z różnych dziedzin, takich jak: prawo, ekonomia i finanse, statystyka oraz organizacja $i$ zarzadzanie. Obejmuje on szereg działań windykacyjnych, których sita jest stopniowana przez bank wraz z uptywem okresu przeterminowania należności. Ostatnim elementem procesu windykacyjnego jest decyzja o sprzedaży przez bank wierzytelności. Niestety praktycznie nie istnieje literatura naukowa opisujaca szczegótowo przebieg procesów windykacyjnych wierzytelności masowych. Publikacja ta powinna wypetnić widoczna lukę $w$ polskojęzycznej literaturze przedmiotu $w$ tym zakresie.
\end{abstract}

Słowa kluczowe: windykacja, proces windykacyjny, odzyskiwanie wierzytelności, sprzedaż wierzytelności, kredyty niepracujące.

Nadesłany: 20.12.2016 | Zaakceptowany do druku: 05.06.2017

\section{Organization of the process of mass claims management in banks}

The article presents the recovery of mass-scale consumer receivables, the process that is so crucial as regards banks' protection against excessive credit risk. Efficient debt collection is extremely important for banks to reduce the share of non-performing loans. It is a long and tedious process requiring specialized knowledge in various fields such as law, economics and finance, statistics, and organization and management. It includes a series of debt collection actions of gradual intensity depending on how long a receivable is overdue. The last element of the debt collection process is the bank's decision to sell receivables. Unfortunately, there is virtually no academic literature describing in detail the course of mass-scale consumer receivable recovery. This publication should fill a visible gap in the Polish-language literature in this respect.

Keywords: collection, collection process, recovery of debt, sales of debt, non performing loans.

Submitted: 20.12.2016 | Accepted: 05.06.2017

JEL: G33, K35

\footnotetext{
Wojciech Kuryłek - dr, Wydział Zarządzania, Uniwersytet Warszawski.

Adres do korespondencji: Wydział Zarządzania, Uniwersytet Warszawski, ul. Szturmowa 1/3, 02-678

Warsząwa; e-mail: wkurylek@wz.uw.edu.pl.
} 


\section{Wprowadzenie}

W literaturze fachowej trudno znaleźć pozycje opisujące procesy windykacyjne w bankach. Wynika to cześciowo z niedostępności danych windykacyjnych banków i jest o tyle interesujące, iż rozwijający się rynek windykacyjny w Polsce stał się istotnym składnikiem rynku kredytowego, który w sposób bardzo szeroki oraz szczegółowy doczekał się już opisu w literaturze. Ta część procesu kredytowego jest jednak niezwykle istotna, gdyż dotyczy ona poziomu tworzonych przez bank odpisów na utrate wartości ekspozycji kredytowych mających bezpośrednie przełożenie na wyniki finansowe banków, a także utrzymania bądź zerwania przez bank umowy kredytowej, a co za tym idzie - relacji z klientem. Jednak nie została ona tak szczegółowo opisana w literaturze przedmiotu. Dlatego dla znacznych części przedstawianych w artykule twierdzeń niemożliwe będzie znalezienie poparcia w źródłach naukowych, ponieważ takich nie ma. Opieraja się one bowiem na specjalistycznej wiedzy oraz doświadczeniu autora.

Prawidłowe zarządzanie należnościami niepracującymi (tzw. Non-Performing Loans $^{1}$ ) jest obowiązkiem banków, zapewniającym odpowiednią jakość ich aktywów. To z kolei znajduje przełożenie na ich rentowność w długim okresie oraz ich poziom ryzyka ${ }^{2}$. Proces odzyskiwania wierzytelności masowych ${ }^{3} \mathrm{w}$ bankach oparty jest na coraz bardziej stanowczych i zdecydowanych działaniach banku, które mają coraz silniejsze konsekwencje finansowe dla klienta Doczekał się on co prawda skromnego opisu w literaturze anglojęzycznej ${ }^{4}$, jednak niewiele publikacji książkowych dostępnych w języku polskim ${ }^{5}$ nie odnosi się zupełnie do odzyskiwania wierzytelności masowych. Publikacja ta powinna wypełnić widoczna lukę w literaturze przedmiotu w języku polskim w tym zakresie.

Proces zarządzania wierzytelnościami w warunkach polskich prezentuje rysunek $1^{6}$

W artykule postaram się bardziej szczegółowo omówić podstawowe składowe procesu windykacyjnego, takie jak restrukturyzacja zadłużenia, wczesny monitoring, późny monitoring, windykacja przesądowa, windykacja sądowa, egzekucja komornicza, outsourcing, sprzedaż wierzytelności bądź jej trwałe spisanie $\mathrm{z}$ bilansu.

\section{Składowe procesu windykacyjnego}

Restrukturyzacja zadłużenia - może występować na każdym etapie postępowania windykacyjnego. Wykonywana jest na wniosek klienta, gdy zostanie zidentyfikowana taka możliwość podczas kontaktu telefonicznego bądź wizyty terenowej przedstawiciela banku, bądź gdy z własne inicjatywy skontaktuje się on z bankiem. Często wymaga ona wniesienia od klienta wpłaty uwiarygodniającej. Zasadniczo wpłaty uwiarygodniajace dokonywane na etapie sądowym powinny pokrywać koszty poniesionych przez bank opłat sądowych, a wpłaty uwiarygodniające dokonywane na etapie egzekucji komorniczej powinny być większe od poniesionych kosztów sądowych

Rysunek 1. Przebieg procesu windykacyjnego wierzytelności masowych w bankach

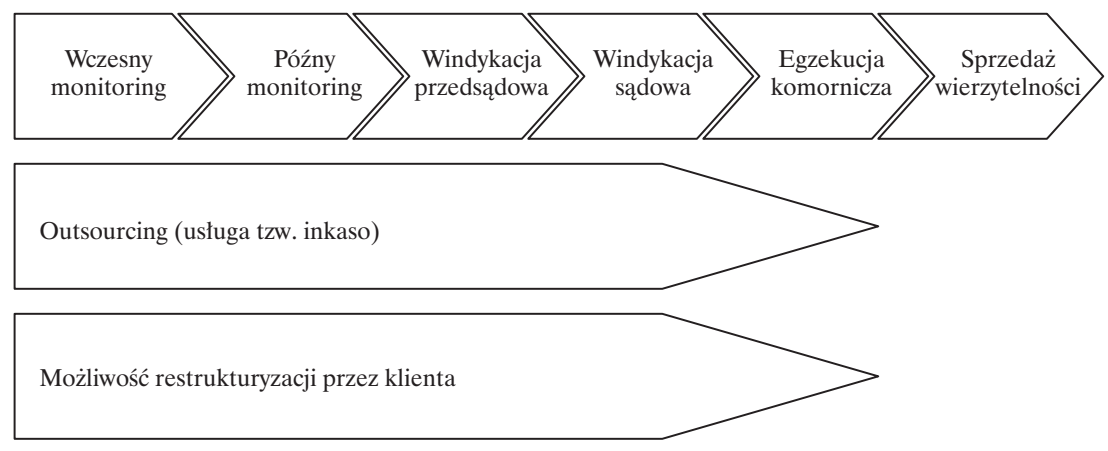

Źródło: opracowanie własne.

Wydział Zarządzania UW ～DOI 10.7172/1733-9758.2017.23.16 
oraz opłat komorniczych. Restrukturyzacja polega na dostosowaniu harmonogramu płatności rat kredytu do możliwości płatniczych klienta. Nie zawsze jednak jest ona możliwa, gdyż klient może nie mieć zdolności kredytowej do spłaty ciążącego na nim zadłużenia - nawet po zaoferowanych mu udogodnieniach w spłacie. Ma ona sens jedynie wówczas, gdy daje szansę na wyjście klienta z długów. Obejmuje ona zmianę warunków umowy kredytowej polegających m.in. na przekształceniu zadłużenia wymagalnego $\mathrm{w}$ niewymagalne, przyjęciu poręczenia, przyjęciu dodatkowego zabezpieczenia rzeczowego, zmianie marży lub oprocentowania, redukcji zadłużenia czy zmianie formuły spłaty (np. kolejności zarachowania wpłat klienta na kapitał, odsetki i koszty). Dla mniejszych kwot możliwe jest zarejestrowanie zmiany umowy kredytowej w postaci nagrania rozmowy telefonicznej, podczas gdy dla większych kwot z przyczyn bezpieczeństwa prawnego bank wymaga podpisania umowy w wersji papierowej. Dla kontraktów o wyższej wartości możliwe jest też podpisanie przez klienta notarialnego oświadczenia o poddaniu się egzekucji, co ogranicza przyszłe koszty sądowe banku oraz znacznie przyspiesza ten etap procesu. Restrukturyzacje w ten sposób zawarte sa kosztowniejsze dla dłużnika oraz wymagające większego jego wysiłku, a przez to trwalsze. Restrukturyzacja jest też jednym z narzędzi zarządzania wskaźnikiem NPL (Non-Performing Loan ratio) w banku. Znaczna część restrukturyzacji może być traktowana bowiem jako restrukturyzacje niezagrożone utratą wartości ekspozycji kredytowej (tzw. NPL-owe), a przez to niewymagające do tworzenia na niej dodatkowych odpisów na utratę wartości. Pewną pokusą dla banku może być przeprowadzenie zbyt dużej liczby restrukturyzacji, gdyż ta może krótkookresowo powodować zarówno poprawę wskaźnika NPL, jak i zmniejszenie w banku odpisów tworzonych na utratę wartości, a przez to - poprawe wyniku finansowego. Jest to jednak zabieg okresowy i skuteczny tylko w bardzo krótkiej perspektywie, w dłuższym horyzoncie czasowym restrukturyzacja musi znajdować uzasadnienie w sytuacji ekonomicznej klienta. Niewłaściwie zrestrukturyzowane kontrakty wracaja bowiem po pewnym czasie do grupy umów, na których stwierdzono utratę wartości oraz pogarszają w przyszłości wskaźnik NPL banku, a jednocześnie grupa dłużników, którzy nie wywiązali się z umowy restrukturyzacyjnej charakteryzuje się znacznie większą postawą roszczeniową, są więc trudniejszym klientem dla banku.

Wczesny monitoring - zaczyna się od pierwszego dnia opóźnienia ${ }^{7}$ w spłacie (DPD - day past due), a kończy na sześćdziesiątym dniu opóźnienia. Okres ten można podzielić na dwa koszyki opóźnieńn: od pierwszego do trzydziestego DPD oraz od trzydziestego pierwszego do sześćdziesiątego DPD. W pierwszym z nich, ze względu na bardzo dużą liczbę kontraktów wpadających w opóźnienia, najbardziej masowo wykorzystywanym narzędziem są SMS-y przypominające klientom o zaległości w płatnościach. Telefony oraz pisma wychodzące do klientów są stosowane w przypadku braku skuteczności SMS-ów i maja przede wszystkim charakter przypominawczy. Okres ten charakteryzuje się wysokim poziomem tzw. samospłat, który potrafi sięgać ponad $50 \%$. W drugim koszyku opóźnień rozmowy z klientami są podstawowym narzędziem i mają charakter bardziej windykacyjny, zmierzający do pozyskania od klienta obietnicy spłaty zaległości. Warto tutaj podkreślić, że przyczyny braku spłaty należności przez klienta bywają różne, począwszy od finansowych, takich jak opóźnione bądź zmniejszone dochody/przychody czy nieplanowane wydatki, po kwestie związane z brakiem pracy, zdrowiem, rodzina lub wyjazdem dłużnika za granice.

Późny monitoring - zaczyna się od sześćdziesiątego dnia opóźnienia w spłacie, a kończy na terminie skutecznego wypowiedzenia umowy kredytowej ${ }^{9}$, tj. około 120-150 DPD. Jest to zwykle termin uskutecznienia wypowiedzenia umowy kredytowej. Podstawowym narzędziem kontaktu z klientem jest kontakt telefoniczny oraz wizyta bezpośrednia specjalisty działu windykacji terenowej. Wizyty terenowe dotyczą przede wszystkim wierzytelności z wyższymi saldami w szczególności takich, w odniesieniu do których klient złamał daną obietnicę spłaty oraz w których kontakt telefoniczny z klientem jest niemożliwy ${ }^{10}$. Oprócz powyższych działań do klienta kierowane są SMSy, e-maile oraz pisma w tym obowiązkowo monit informujący o możliwości zrestrukturyzowania zadłużenia, który wysyłany jest przed wypowiedzeniem umowy kredytowej, a w przypadku jego nieskuteczności - samo jej wypowiedzenie. W odnie- 
sieniu do istotnej części umów dopiero zastosowanie tego ostatecznego narzędzia, jakim jest wypowiedzenie umowy kredytowej, przynosi skutek w postaci spłaty przez klienta zaległości bądź wstąpienia przez niego z wnioskiem o restrukturyzację kredytu.

Windykacja przedsądowa - zaczyna się z chwilą skutecznego wypowiedzenia klientowi umowy kredytowej, a kończy z chwilą wysłania pozwu do sądu. Na tym etapie rozmowy $z$ klientem są jeszcze trudniejsze, gdyż do spłaty zadłużenia bądź jego restrukturyzacji nie skłoniło go nawet otrzymanie wypowiedzenia umowy kredytowej. $\mathrm{Z}$ reguły ten etap procesu świadczy o poważnych trudnościach klienta w spłacie zadłużenia bądź jego niechęci do jego spłaty oraz wypieraniu ze świadomości możliwych konsekwencji braku spłaty zobowiązań. W tym okresie wysyłane jest również przedsądowe wezwanie do zapłaty ${ }^{11}$.

Przypadki unikania przez klientów odbioru tego pisma (nie podejmowanie awiz, zmiany adresów zamieszkania, wyjazdy z kraju) moga skutkować podejmowaniem dodatkowych działań przez bank ${ }^{12}$.

Windykacja sądowa - zaczyna się z chwila wysłania pozwu do sądu, a kończy w momencie uzyskania prawomocnego tytułu wykonawczego. Ze względu na jej kosztowność rozpoczyna się ją w odniesieniu do kontraktów, których wielkość przekracza próg opłacalności, tj. wielkość, powyżej której oczekiwana wartość wpływów z tytuł dalszej windykacji przewyższa koszty jej prowadzenia. Może przybrać formę zwykłego postępowania nakazowego badź postepowania w ramach Elektronicznego Postępowania Upominawczego ${ }^{13}$. Różnica w wyborze ścieżki postępowania dotyczy sposobu ponoszonych przez wierzyciela kosztów, długości postępowania, a przede wszystkim jego pracochłonności dla wierzyciela. Wnosząc pozew do sądu, należy uiścić opłatę ${ }^{14}$. Opłatę stosunkową pobiera się w sprawach o prawa majątkowe w wysokości $5 \%$ wartości przedmiotu sporu lub przedmiotu zaskarżenia, jednak nie mniej niż 30 zł i nie więcej niż 100000 zł15. $\mathrm{W}$ postępowaniu nakazowym od pozwu pobiera się czwarta część opłaty, natomiast trzy czwarte części opłaty pobiera się od pozwanego w razie wniesienia zarzutów od nakazu zapłaty wydanego w postępowaniu nakazowym, przy czym opłata nie może wynosić mniej niż 30 zł16. Odmienna wysokość opłaty stosowana jest w postępowaniu upominawczym. Pozew musi być opłacony w pełnej wysokości, z tym że sąd z urzędu zwraca stronie trzy czwarte uiszczonej opłaty od pozwu w postepowaniu upominawczym, jeżeli uprawomocnił się nakaz zapłaty ${ }^{17}$. Przewidziana w powyższym przepisie ułamkowa opłata odnoszona jest do wysokości całej opłaty. Tak więc w przypadku postępowania zarówno nakazowego, jak i upominawczego koszt dla wierzyciela to $1,25 \%$ przedmiotu sporu, który dopisywany jest do zadłużenia dłużnika. Natomiast $\mathrm{w}$ aspekcie długości postępowania w przypadku zachowania w całości drogi postępowania elektronicznego termin od wniesienia pozwu do otrzymania prawomocnego tytułu wykonawczego jest zbliżony i wynosi 4-5 miesięcy. Problem pojawia się wówczas, gdy sędzia w e-Sądzie ${ }^{18}$ przekazuje do rozpoznania sprawę do jednego z 321 (stan na 31 maja 2017 r.) sądów rejonowych, co potrafi trwać kolejne 5-6 miesiecy. Dzieje sie tak w przypadku wątpliwości sędziego bądź wniesienia przez dłużnika sprzeciwu. Najważniejszym aspektem różnicującym wybieraną przez wierzyciela ścieżkę postępowania jest jednak pracochłonność. Oprócz samej papierowej wersji przedstawianych sądowi dowodów w postępowaniu nakazowym należy również, po otrzymaniu z sądu nakazu, wystąpić do niego $\mathrm{z}$ wnioskiem o doreczenie go dłużnikowi. Na kolejnym etapie procesu prawomocny tytuł wykonawczy musi być również $\mathrm{w}$ formie papierowej dostarczony do komornika. Wszystko powyższe niesie za sobą dużą skalę problemów operacyjnych oraz kosztów z nimi związanych. W przypadku Elektronicznego Postępowania Upominawczego zarówno korespondencja z sądem, jak i skierowanie wniosku do komornika odbywa się elektronicznie. Dlatego też powszechnie stosowaną praktyka jest kierowanie do sądu umów nisko i średnio kwotowych, których jest bardzo wiele, w formie elektronicznej ${ }^{19}$. Należy w tym momencie wspomnieć o dodatkowych kosztach zastępstwa procesowego, które moga obciążyć dłużnika i być dla niego nieprzyjemnym zaskoczeniem ${ }^{20}$. Warto dodać, że na tym etapie bank jako wierzyciel przestaje kontaktować się z własnej inicjatywy $\mathrm{z}$ dłużnikiem. Bank po skierowaniu pozwu do sądu także jest otwarty na propozycje oraz rozmowę z dłużnikami, jednak propozycja ugodowego rozwiązania kwestii 
zadłużenia musi wyjść z ich inicjatywy oraz to oni powinni w tej sytuacji pokryć koszty związane z opłatami sądowymi.

Egzekucja komornicza - rozpoczyna sie z chwila skierowania przez wierzyciela wniosku egzekucyjnego do komornika, a kończy w przypadku braku możliwości wyegzekwowania zadłużenia umorzeniem przez komornika albo wierzyciela postepowania egzekucyjnego bądź też sprzedażą wierzytelności w czynnym postępowaniu egzekucyjnym. Skierowanie wniosku egzekucyjnego pociaga za sobą konieczność wpłacenia komornikowi ${ }^{21}$ zaliczki. Należy rozróżnić sprawy, w których prowadzona jest egzekucja $\mathrm{z}$ nieruchomości oraz te, które dotyczą pozostałych składników majątku dłużnika. W pierwszym z powyższych przypadków komornikiem właściwym jest komornik z rewiru, w obrębie którego zlokalizowana jest nieruchomość. W drugim z nich sprawę taką może obsługiwać komornik z dowolnego rewiru w Polsce pod warunkiem, że działa w ramach ustawowego limitu przydziału spraw i nie wykazuje statystycznych zaległości w obsłudze spraw ${ }^{22}$ Standardowym elementem egzekucji wierzytelności zabezpieczonej hipotecznie jest dokonanie na zlecenie komornika opisu i oszacowania nieruchomości, które wykonuje rzeczoznawca majątkowy ${ }^{23}$. Następnie w siedzibie sądu przeprowadzana jest pierwsza licytacja nieruchomości, na które ceną wywołania jest kwota stanowiąca $75 \%$ kwoty wynikajacej z opisu i oszacowania nieruchomości. W przypadku nieskutecznej licytacji sad wyznacza termin drugiej licytacji nieruchomości, w której ceną wywołania jest $66 \%$ kwoty wynikającej z opisu i oszacowania nieruchomości. Można przyjąć, że okres, który upływa od momentu wszczęcia egzekucji do drugiej licytacji nieruchomości to przedział 1-1,5 roku. W przypadku przeprowadzenia skutecznej licytacji dalszymi krokami są wydanie przez sąd postanowienia o przybiciu, zapłata przez nabywcę całości ceny, przysądzenie własności przez są oraz zatwierdzenie przez sąd planu podziału. Należy zwrócić uwagę, że potrafią one trwać nawet kolejny rok. Tak, więc wierzyciel otrzymuje środki na rachunek często po ponad dwóch latach od wszczęcia egzekucji. Warto tutaj powtórzyć, iż egzekucja z nieruchomości nie wyklucza prowadzenia jej z innych składników majątku dłużnika. Egzekucja wierzytelności niezabezpieczonych hipotecznie pro- wadzona jest według odmiennych modeli. Generalnie praktykowane są dwa modele współpracy - scentralizowany oraz zdecentralizowany. Model zdecentralizowany oparty jest na współpracy z bardzo dużą liczbą komorników - co najmniej jednym w każdym rewirze komorniczym. Wymaga on poświęcenia większych zasobów ludzkich do ich monitorowania oraz trudniejsze jest zarządzanie kosztami egzekucji. Występują w nim także trudności w raportowaniu przez komorników ich czynności, a ich standaryzacja jest praktycznie niemożliwa. Praktycznie niemożliwa jest także standaryzacja w rozliczeniach finansowych bank komornicy. Komornicy bardziej odczuwaja „monopol” w danym rewirze, co ogranicza między nimi zdrową rynkową konkurencję. Niewielka liczba wniosków, jaką może skierować w tym modelu bank do jednej kancelarii komorniczej, sprawia, że także motywacja finansowa do dopasowania działań kancelarii do oczekiwań banku nie jest duża. Model ten jednak ze względu na swój lokalnych charakter powoduje iż komornik jest bliżej dłużnika, przez co może teoretycznie być bardziej skuteczny. Pozwala on także nie brać pod uwagę ustawowych limitów spraw, jakie w ciągu roku moga trafić do komornika spoza jego rewiru na mocy art. 8 „Ustawy o komornikach sądowych i egzekucji”. Jego przeciwieństwem jest model scentralizowany, w którym wierzyciel współpracuje z ograniczoną liczbą komorników. Jest on dla wierzyciela dużo mniej pracochłonny, latwy do standaryzacji współpracy oraz raportowania, a także rozliczeń finansowych. Jednak najważniejszą jego cechą jest to, że wymusza na nich konkurencję. Model zdecentralizowany stosowany jest na ogół przez duże firmy windykacyjne kierujące rokrocznie olbrzymie ilości spraw do egzekucji komorniczej i przez to nie mogące „zmieścić się” w narzuconych ustawowo limitach spraw spoza rewiru, jakie może przyjąć komornik. Wykorzystywany jest on także przez pozostałych wierzycieli w przypadku egzekucji niezabezpieczonych hipotecznie ekspozycji o wysokich kwotach. Czestym rozwiazaniem wykorzystywanym w praktyce jest model „hybrydowy”, w którym sprawy nisko kwotowe obsługiwane są w modelu ,scentralizowanym", podczas gdy sprawy wysoko kwotowe przekazywane są do komorników rewirowych. W takim modelu zazwyczaj różnicuje się oczekiwania w stosunku do 
zakresu podejmowanych czynności przez komornika. W zależności od kwoty opłaconej zaliczki komornik może m.in. wykonać takie czynności, jak poszukiwanie majątku, zajęcie emerytury, renty, wynagrodzenia, rachunku bankowego, ruchomości, nieruchomości oraz wierzytelności. Warto tutaj zauważyć, że wniosek do komornika powinien zawierać jak najwięcej danych pozwalających na zidentyfikowanie składników majątku dłużnika oraz taki zakres składników majątku, z których może być prowadzona egzekucja i pozwalający na jej szerokie i efektywne prowadzenie. Przy wyższych kwotach w celu zidentyfikowania składników majątku dłużnika może okazać się opłacalne użycie agencji detektywistycznej. Na uwagę zasługuje również waga wszczęcia egzekucji komorniczej w aspekcie podatkowym. Umożliwia bowiem ona zaliczenie do kosztów uzyskania przychodów, w ujęciu ustawy o CIT, kwoty niewyrezerwowanej/nieodpisanej poprzez uprawdopodobnienie badź udokumentowanie nieściagalności danej wierzytelności ${ }^{24}$. Oznacza to w praktyce konieczność wszczęcia egzekucji komorniczej. Również na tym etapie bank jako wierzyciel nie kontaktuje się $\mathrm{z}$ własnej inicjatywy z dłużnikiem, ale jest nadal otwarty na propozycje dłużników, muszą one jednak wyjść z ich inicjatywy. Minimalnym wymogiem do zawarcia ugody w te sytuacji jest zazwyczaj pokrycie przez dłużnika kosztów związanych z opłatami sądowymi oraz egzekucyjnymi 25 .

Outsourcing - polega na zleceniu podmiotowi zewnętrznemu wykonywania czynności windykacyjnych. Może ono dotyczyć wszystkich $\mathrm{z}$ powyższych etapów windykacji, począwszy od wczesnego monitoringu, a skończywszy na egzekucji komorniczej. Podstawową różnicą we współpracy z zewnętrznymi dostawcami na etapie przed sądowym i sądowo-egzekucyjnym jest podstawa prawna współpracy oraz profil firmy zewnętrznej. Na etapie przedsądowym dostawcami są duże firmy windykacyjne na etapie sadowo-egzekucyjnym - głównie wyspecjalizowane kancelarie prawne. Dostawcy wybierani są zwykle na zasadzie przetargu. Umowy outsourcingowe dotyczące windykacyjnej obsługi umów na zlecenie, a także dotyczące pomocy prawnej oparte są z reguły tylko na success fee i ewentualnie na etapie sądowo-egzekucyjnym obejmują także koszty zastępstwa egzekucyjnego. Rośnie ono wraz $\mathrm{z}$ etapem procesu windykacji obsługiwanym przez dostawcę, najniższe jest dla wczesnego monitoringu oraz najwyższe dla egzekucji komorniczej. Na etapie sądowym zakłada sie zwracanie przez bank zewnetrznej kancelarii prawnej poniesionych kosztów opłat sadowych, a na etapie komorniczym kosztów zaliczek komorniczych, jak i również kosztów sporządzenia operatów szacunkowych nieruchomości. Bank opłaty te dopisuje do konta klienta, powiększając o nie jego zadłużenie, analogicznie jak przy działaniach podejmowanych przez bank. Należy dodać, że usługi outsourcingowe mogą dotyczyć również innych pomniejszych czynności windykacyjnych, takich jak poszukiwanie ksiąg wieczystych dłużników, danych telefonicznych czy pośredniczenie w pomocy sprzedaży przez dłużników nieruchomości ${ }^{26}$ stanowiących zabezpieczenie kredytu. W przypadku outsourcingu można zasadniczo wyróżnić trzy modele jego wykorzystywania. W pierwszym z nich wyniki uzyskiwane przez outsourcera traktujemy jako benchmark dla wewnętrznych procesów windykacyjnych banku. Proste porównanie efektywności wewnętrznej z uzyskiwaną przez outsourcera może być jednak w praktyce trudne do precyzyjnego zdefiniowania, gdyż nie wszystkie typy kontraktów są przez niego obsługiwane w przeciwieństwie do wewnętrznych służb windykacyjnych ${ }^{27}$. W drugim wypadku do outsourcera kierujemy umowy gorszej jakości, zrzucając na niego trudniejszą do wykonania pracę, a sprawy łatwiejsze do obsługi pozostawiamy wewnętrznej windykacji. Ten model współpracy uniemożliwia porównanie skuteczności wewnętrznej windykacji z tą uzyskiwaną przez zewnętrznego dostawcę. Uniemożliwia to poprawę efektywności wewnętrznych procesów 28 . Trzeci model współpracy polega na zleceniu outsourcerowi obsługi tych kontraktów, których obsługa jest niemożliwa wewnętrznymi siłami banku $\mathrm{z}$ przyczyn braków zasobów bądź kompetencji. W tym miejscu należy wspomnieć, iż niezwykle trudno jest porównać precyzyjnie koszt odzyskania 1 złotówki ${ }^{29}$ dla procesu realizowanego wewnątrz oraz zlecanego outsourcerowi. O ile łatwo wyznaczyć go w przypadku firm windykacyjnych, o tyle trudno go wyznaczyć dla ściśle określonych procesów wewnętrznych, zwłaszcza gdy różne etapy benchmarkowanego procesu realizowane są przez ten sam zespół osób w banku. 
Sprzedaż wierzytelności - następuje $z$ reguły na ostatnim etapie procesu windykacji, w sytuacji, gdy dotychczasowe działania banku nie doprowadziły do spłaty należności przez dłużnika bądź jej zrestrukturyzowania. Dokonywana może być na podstawie postanowień kodeksu cywilnego ${ }^{30}$ lub ustawy o restrukturyzacji finansowej przedsiębiorstw i banków oraz zmianie niektórych ustaw ${ }^{31}$ oraz prawo bankowe ${ }^{32}$, choć najczęściej wybieraną opcją jest k.c. Różnią się one bowiem zasadniczo w zakresie obowiązku informacyjnego wierzyciela ${ }^{33}$. Ustawa - Prawo bankowe wprowadza również obowiązkowe kryteria wyboru wierzytelności, jakie moga być kierowane przez banki do sprzedaży. Muszą one należeć do kategorii ryzyka „stracone”34. Sprzedaż wierzytelności przez banki wynika $\mathrm{z}$ czterech następujących przyczyn. Po pierwsze, bank może uzyskać w stosunkowo szybkim czasie cenę ze sprzedaży zamiast prowadzenia długotrwałego i kosztownego procesu odzyskiwania wierzytelności, który często sięga kilku lat ${ }^{35}$. Po drugie, w wyniku tej operacji następuje oczyszczenie bilansu banku z aktywów niepracujących, co umożliwia bankowi utrzymanie pod kontrolą wskaźnika kredytów niepracujących (NPL ratio $)^{36}$, który jest obserwowany przez krajowych i międzynarodowych analityków bankowych oraz inwestorów. Po trzecie, wprowadzanie podatku bankowego ${ }^{37}$ powoduje, iż bank co miesiac musi uiszczać danine publiczna w wysokości $0,0366 \%$ wartości znajdujące się w jego bilansie części wierzytelności w ujęciu netto ${ }^{38}$, czego można uniknąć, sprzedając daną wierzytelność. Po czwarte, odpowiednie ustrukturyzowanie transakcji sprzedaży pozwala na uzyskanie na niej korzyści podatkowej przez bank (tzw. tarczy podatkowej) polegającej na zaliczeniu do podatkowych kosztów uzyskania przychodów dyskonta, z jakim sprzedawane są kredyty. Najczęściej z przyczyn podatkowych, by móc zaliczyć stratę na sprzedaży do kosztów uzyskania przychodów, sprzedaż wierzytelności następuje dopiero po uprawdopodobnieniu bądź udokumentowaniu nieściągalności danej wierzytelności. W praktyce oznacza to co najmniej wszczęcie przez wierzyciela egzekucji komorniczej $^{39}$. Sprzedaż na wcześniejszym etapie jest możliwa, lecz pozbawia ona bank możliwości zaliczenia straty na sprzedaży wierzytelności do kosztów podatkowych, czyli pozbawia go znaczącej tarczy podatkowej w wysokości 19\% straty. Dzieje się tak wówczas, gdy bankowi zależy bardziej na obniżeniu wskaźnika NPL (Non-Performing Loan ratio) i nie może on z przyczyn czasowych uzyskać korzyści podatkowej. Należy tutaj wspomnieć, iż to dopiero wprowadzona w 2004 roku ustawa o funduszach inwestycyjnych dała możliwość uznania przez organy skarbowe dyskonta przy sprzedaży jako kosztu uzyskania przychodów dla banku, co było kamieniem milowym w rozwoju rynku sprzedaży wierzytelności w Polsce i umożliwiła dalszy szybki jego rozwój.

W odniesieniu do możliwości rozpoznania straty na sprzedaży w ciężar kosztów podatkowych ustawa ta wprowadziła obowiązek, aby kupującym portfele wierzytelności był fundusz sekurytyzacyjny.

Struktura transakcji nabycia wierzytelności od banku w Polsce została zaprezentowana rysunku 2, przy czym inwestorem w funduszu sekurytyzacyjnym może być sama firma windykacyjna bądź też inwestorzy w fundusze sekurytyzacyjne moga być niezależnymi od niej podmiotami ${ }^{40}$. Najważniejszymi etapami sprzedaży są due dilligence przeprowadzany przez inwestora oraz mechanizm pozwalający na określenie finalnej ceny transakcji w oparciu o dane pozyskane na tym etapie. Due dilligence przeprowadzane jest na podstawie plików bazodanowych z wykazami wierzytelności, a także przy użyciu tzw. Virtual Data Room pozwalającego na przeglądanie skanów dokumentacji kredytowej zamiast ich papierowej wersji, co jest wygodniejsze zarówno dla inwestorów, jak i dla banku. Odmiennie proces ten wygląda dla wierzytelności masowych - przede wszystkim niezabezpieczonych hipotecznie oraz wierzytelności zabezpieczonych hipotecznie ${ }^{41}$. W odniesieniu do wierzytelności masowych zarówno due dilligence czy wycena portfela, jak i samo ustalenie propozycji cenowej ma charakter statystyczny. Jest ono zasadniczo oparte na danych udostepnianych potencjalnym nabywcom w formie pliku bazodanowego/excelowego ${ }^{42}$ zawierającego dane finansowe oraz socjodemograficzne dla poszczególnych kontraktów ${ }^{43}$. Obejmuje on m.in. takie dane, jak: wiek dłużnika ${ }^{44}$; jego płeć45; wykształcenie; zawód i wysokość jego dochodu ${ }^{46}$; okres zalegania ${ }^{47}$ oraz podejmowane czynności windykacyjne ${ }^{48}$. Przyszły nabywca bada jego zgod- 


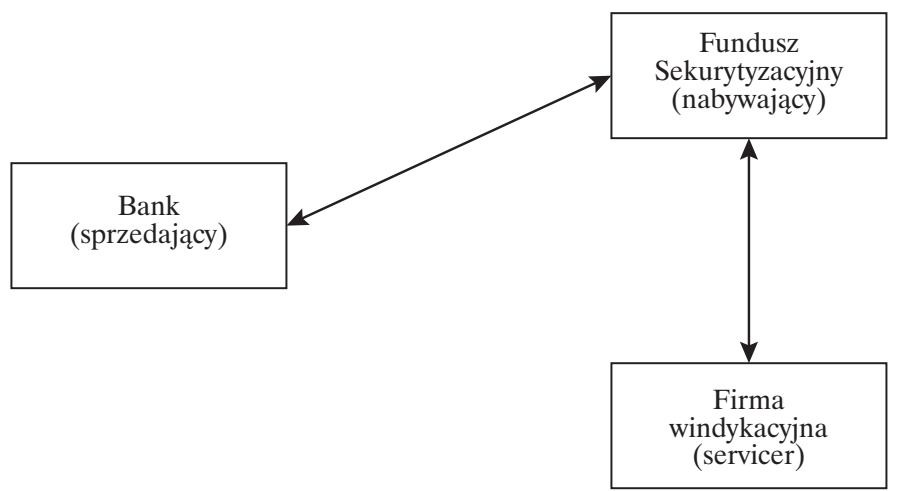

Źródło: opracowanie własne.

ność z danymi zawartymi w dokumentacji kredytowej i badanie to zwykle obejmuje niewielką część przekazanego do wyceny portfela, mając charakter statystyczny. Kluczowa z tego punku widzenia jest jakość przekazanych danych oraz dokumentacji kredytowej. Zła ich jakość może bowiem w sposób znaczący wpłynąć na zaoferowane ceny, gdyż nabywca w tej sytuacji musi się zabezpieczyć przed niekorzystnym dla niego scenariuszem związanym z jakością kupowanego portfela ${ }^{49}$. Wyniki tego badania stanowią podstawę do określenia przez niego wiążącej dla niego oferty cenowej. Proces wyceny wygląda zgoła inaczej dla wierzytelności zabezpieczonych hipotecznie ${ }^{50}$. Dane przekazane uczestnikom postępowania przetargowego, oprócz powyższych danych zawartych w data tape, obejmują również dane odnoszace sie do numerów ksiąg wieczystych nieruchomości stanowiących zabezpieczenie kredytu. Tutaj jednak proces due dilligence nie ma charakteru statystycznego tylko indywidualny i wymaga przebadania dokumentacji kredytowej prawie całego sprzedawanego portfela. Takie portfele są znacznie mniej liczne od portfeli masowych ${ }^{51}$. Badanie to opiera się $\mathrm{w}$ tym przypadku przede wszystkim na wycenie przez potencjalnego nabywcę przedmiotu zabezpieczeń portfela, tj. nieruchomości. Należy tutaj podkreślić, że kluczową datą w procesie sprzedaży nieruchomości jest data wyceny, która jest wiążąca dla przyszłych nabywców. Oznacza to, iż zaoferowana przez nich cena musi zostać zapłacona po jej przedstawieniu bankowi, jeśli ten zdecyduje się wybrać daną ofertę.
Warto nadmienić, iż data ta jest kluczowa z punktu widzenia rozliczeń między sprzedawcą oraz nabywcą portfela wierzytelności. Otóż wszelkie zmiany w sprzedawanym portfelu, w tym wycofania $\mathrm{z}$ niego kontraktów po tej dacie, powinny pociagacć za sobą konsekwencje finansowe, gdyż to on stanowił podstawę do wyceny portfela przez przyszłego nabywcę. $Z$ reguły wprowadzony mechanizm polega na zwrocie nabywcy zapłaconej ceny za portfel w proporcji, jaką część wartości sprzedawanego portfela stanowi wycofywana wierzytelność. Cena otrzymywana ostatecznie w procesie sprzedaży może różnić się znacznie od ceny wiążącej. Dzieje się tak dzięki zastosowaniu mechanizmu cenotwórczego, jakim jest aukcja ceny, w której ceną wywoławczą jest cena wiążąca przedstawiona przez oferentów. Może ona w zależności od kanału kontaktu banku z oferentami mieć formę elektroniczną, bezpośrednią-ustną, telefoniczną. Organizując ją, należy wziąc pod uwagę takie jej elementy, jak preferencje oferentów, w tym te dotyczące transparentności procesu, możliwości ich dotarcia w wyznaczonym czasie na wyznaczone miejsce oraz koszt logistyki związanej z organizacja procesu aukcji. W Europie Zachodniej oraz w Stanach Zjednoczonych najbardziej popularną formą są aukcje elektroniczne, podczas gdy w Polsce są nią licytacje telefoniczne. Ostateczna cena zostaje jednak zdeterminowana podczas aukcji w czasie rynkowej gry popytu oraz podaży. Może ona różnić się zasadniczo od cen, które otrzymują inwestorzy z modeli wyceny, gdyż po pierwsze różni inwesto- 
rzy dysponują różnymi danymi oraz modelami wyceny, a także podczas aukcji w grę mogą wchodzić emocje związane z tym, który z konkurentów rynkowych stara się nabyć ten sam portfel oraz wpływ może mieć także chwilowa dostępność kapitału na rynku w okresie organizacji aukcji. Czynniki te mogą często prowadzić do mniej racjonalnych zachowań inwestorów. Finalna cena zostaje zapłacona zwykle przez zwycięzcę licytacji po uzyskaniu zgody na sprzedaż wierzytelności przez odpowiednie organy banku w dniu cesji wierzytelności. W tym aspekcie szczególną rolę odgrywa dyscyplina cenowa kupującego oraz to, na ile ostateczna cena transakcji różni od ceny wynikającej z dobrze przeprowadzonej wyceny nabywanego portfela, mającej rzeczywiste uzasadnienie w generowanych przez niego dla nabywcy przyszłych przepływach pieniężnych ${ }^{52}$. Zbyt optymistyczne założenia mogą bowiem prowadzić do dużo niższej niż oczekiwana rentowności dla inwestora lub nawet jego strat na kupowanym portfelu.

Na koniec warto wspomnieć, że sprzedaż wierzytelności ma istotny wpływ nie tylko na wynik banków, o czym już wspomniano, lecz także jest ważnym elementem gospodarki pozwalającym częściowo udrażniać powstające zatory płatnicze. Rynek windykacyjny ${ }^{53}$ rósł w ostatnich latach bardzo szybko, co przedstawia rysunek 3 .

Trwałe spisanie wierzytelności z bilansu - powoduje usunięcie kontraktu z ewidencji bilansowej banku. Nie jest to jednak jedyna taka sytuacja. Obejmuje ono także przypadki wierzytelności, których bank nie może dalej dochodzić i nie może bądź nie chce ich sprzedać. Może to dotyczyć m.in. przypadków zakończonych postępowań upadłościowych, oszustw wewnętrznych bądź zewnętrznych oraz spraw, w których sąd podważył zasadność spłaty zadłużenia przez dłużnika. W praktyce oznacza ono zaprzestanie czynności związanych z dochodzeniem rzez bank należności wobec klienta.

\section{Wnioski}

Jak wynika z powyższej analizy, proces odzyskiwania należności jest kluczowy dla obrony banku przed zbyt dużym ryzykiem kredytowym. Efektywne prowadzenie działań windykacyjnych ma bowiem niezwykle istotny wpływ na obniżanie przez bank wskaźnika udziału kredytów niepracujących (tzw. NPL). Jest to proces długi i żmudny oraz wymagający specjalistycznej wiedzy z różnych dziedzin, takich jak prawo, ekonomia i finanse, statystyka oraz organizacja i zarzadzanie. Obejmuje on wiele działań windykacyjnych, których siła jest stopniowana przez bank wraz $\mathrm{z}$ upływem okresu przeterminowania należności. Im wierzytelność jest bardziej opóźniona, tym działania banku są bardziej zdecydowane i pociągają większe konsekwencje finansowe dla klienta. Trzeba tutaj dodać, że restrukturyzacja zadłużenia przez klienta jest praktycznie możliwa na każdym etapie życia kontraktu. Musi mieć ona jednak uzasadnienie ekonomiczne w sytuacji finansowej klienta.

Rysunek 3. Sprzedaż portfeli wierzytelności w Polsce

Wartość portfeli wierzytelności sprzedanych w Polsce (w mld. PLN)

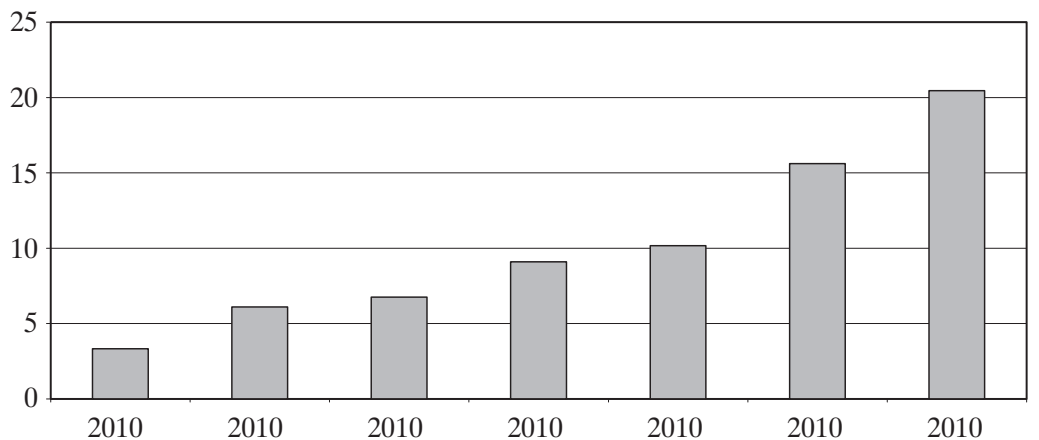

Źródło: Wielkość polskiego rynku wierzytelności zarządzanego przez członków KPF, IV kw 201654. 
Bardzo ważnym elementem procesu windykacyjnego jest decyzja o sprzedaży przez bank wierzytelności. Istnieje cały szereg uwarunkowań tej decyzji, które zostały wymienione w tym artykule.

Publikacja ta powinna wypełnić widoczną lukę w literaturze przedmiotu, jednak nie obejmuje ona takich kwestii, jak omówienie miar efektywności procesowej wykorzystywanych w windykacji, wewnętrznych modeli usytuowania procesu windykacyjnego w strukturze organizacyjnej banku oraz problemów związanych z wyceną portfeli wierzytelności. Wymagają one dalszego opracowania oraz badań w tym zakresie.

\section{Przypisy}

1 Główne determinanty NPL to: wzrost gospodarczy, bezrobocie, zyskowność banku opisująca jakość jego zarządzania oraz współczynnik kredytów do depozytów wskazujący na jakość zarządzania ryzykiem (za: Anastasiou, Louri i Tsionas, 2016).

2 Wskazuje na to Europejski Bank Centralny (w: Constancio, 2017; Enria, 2017).

3 Za wierzytelności masowe uznaje się wierzytelności od klientów indywidualnych oraz małych i średnich przedsiębiorstw.

4 Kluczową publikacją anglojęzyczną jest Deville, 2015.

5 Waldemar Podel (2014) porusza przede wszystkim prawne aspekty procesu windykacji, nie odnosząc się do procesu organizacji odzyskiwania wierzytelności masowych. Z kolei Monika Bekas-Nowak (2008) odnosi się do minimalizowania ryzyka powstania przeterminowanych należności oraz opisu generalnych zasad ich odzyskiwania, nie skupiając się na specyfice wierzytelności masowych. Podobnie Jarosław Holwek (2006) skupia się przede wszystkim na aspekcie negocjacyjnym windykacji, a nie organizacji samego procesu. Najbardziej zbliżoną tematycznie jest publikacja Katarzyny Kreczmańska-Gigol (2015), choć nie przedstawia ona tematu w sposób zwięzły.

6 Peter von Goetz (2004) z Bank for Internationa Settlements opisuje dosyć szczegółowo proces windykacyjny z uwzględnieniem sprzedaży wierzytelności.

7 Część banków dla klientów regularnie wpadajacych w opóźnienia stosuje także tzw. pre-monitoring, który polega na wysyłaniu SMS-ów i e-maili przypominających na 1-3 dni przed terminem płatności raty.

8 Koszyk opóźnień jest pojęciem technicznym w branży windykacyjnej opisującym te kontrakty, które charakteryzują się opóźnieniami z przedziału 1-30 DPD (1 koszyk), 31-60 DPD (2 koszyk), 61-90 DPD (3 koszyk), 91-120 DPD (4 koszyk) i 121-150 DPD (5 koszyk) itd.

9 Wypowiedzenie umowy kredytowej uskutecznia się z chwilą otrzymania przez bank zwrotnego potwierdzenia odbioru, które stwierdza skuteczne doreczenie klientowi wypowiedzenia oraz w przypadku braku spłaty zaległości przez klienta w uzgodnionym terminie (czesto jest to okres do 30 dni) od jego otrzymania, gdyż często wypowiedzenie ma formę warunkową w odniesieniu do klientów indywidualnych, tj. może zostać cofnięte w przypadku spłaty klienta bądź skierowania przez niego wniosku o restrukturyzację długu. W praktyce potwierdzenie doręczenia klientowi wypowiedzenia oznacza otrzymanie przez bank tzw. zwrotnego potwierdzenia odbioru, które może mieć forme papierową bądź elektroniczną. Przed samym wysłaniem wypowiedzenia do klienta wysyłany jest monit przypominający o zaległości. Wynika on $\mathrm{z}$ art. $75 \mathrm{c}$ ustawy - Prawo bankowe, art. 6 ust. 1 „nowej” ustawy o kredycie konsumenckim z 2011 roku który odwołuje się wprost do art. 14 ,starej” ustawy o kredycie konsumenckim z 2001 r.

10 Problem kontaktowalości klientów jest podstawowym zagadnieniem w branży windykacyjnej, gdyż posiadane dane teleadresowe nie sa $\mathrm{z}$ reguły dostatecznie czesto i prawidłowo aktualizowane oraz część klientów mających problemy ze spłata zadłużenia celowo unika kontaktów z bankiem. W przypadku braku prawidłowych danych adresowych istnieje jednak możliwość wystąpienia do Centrum Personalizacji Danych w celu ich uaktualnienia Z kolei w przypadku nieprawidłowych danych telefonicznych głównym źródłem pozyskiwania danych sa dostepne u operatorów telefonicznych publiczne książki telefoniczne oraz świadczone przez zewnętrznych dostawców usługi polegające na integracji tych danych w postaci elektronicznej.

11 Obowiązek jego wysłania wynika z art. 187 par. 1 oraz art. 485 par. 3 kodeksu cywilnego.

12 W takim przypadku można wystapić z wnioskiem do sądu o ustanowienie kuratora.

13 Do 1 sierpnia 2016 r. istniała możliwość wystawiana przez banki Bankowych Tytułów Wykonawczych (tzw. BTE), która dawała możliwość szybszego (ok. 2 miesięcy) oraz tańszego (towarzyszył temu koszt w wysokości 50 zł) uzyskania klauzuli wykonalności. Wyeliminowanie BTE z polskiego systemu prawnego stało się faktem w dniu wejścia w życie ustawy z dnia 25 września 2015 r. o zmianie ustawy - Prawo bankowe oraz niektórych innych ustaw (Dz. 2015 poz. 1854). Uchylne zostały art. o BTE tj. art. 96-98. Trybunał Konstytucyjny w wyroku $\mathrm{z}$ dnia 14 kwietnia 2015 r. (sygn. akt P 45/12) orzekł, że BTE jest sprzeczny z konstytucją. 
14 Art. 2 ust. 2 i art. 3 ust. 2 ustawy z 28.7.2005 r. o kosztach sądowych w sprawach cywilnych.

15 Art. 13 ustawy o kosztach sądowych w sprawach cywilnych.

16 Art. 19 ust. 2 i 4 oraz art. 20 ust. 1 ustawy o kosztach sądowych w sprawach cywilnych.

17 Art. 79 ust. 2 pkt 2 lit. c ustawy o kosztach sądowych w sprawach cywilnych.

18 Jest to Sad Rejonowy Lublin-Zachód w Lublinie rozpatrujący pozwy w ramach Elektronicznego Postępowania Upominawczego. W zdecydowanej większości rozpatruje on drobne pozwy kierowane przez firmy windykacyjne.

19 Często w firmach windykacyjnych oraz bankach kwotą oddzielającą sprawy kierowane do sądu w formie papierowej od elektronicznej jest 100 tys. złotych.

20 Reguluje to ustawa z dnia 6 lipca 1982 r. o radcach prawnych oraz rozporządzenie Ministra Sprawiedliwości z dnia 22 października 2015 r. w sprawie opłat za czynności radców prawnych.

21 W Polsce na dzień 31 maja 2017 roku było 1661 komorników skupionych w 321 rewirach.

22 Wynosi on zgodnie $\mathrm{z}$ art. 8 ustawy $\mathrm{z}$ dnia 29 sierpnia 1997 r. o komornikach sądowych i egzekucji zasadniczo 5000 spraw bądź w przypadku wyższej efektywności komornika 10000 spraw, które komornik może przyjąć spoza rewiru.

23 Najczęściej jest on także biegłym sądowym by uchronić się przed ewentualnymi skargami dłużnika.

24 Art. 16 ust. 1, 2 i 2a ustawy z dnia 15 lutego 1992 r. o podatku dochodowym od osób prawnych (t.j. Dz.U. z 2011 r. Nr 21, poz. 397 ze zm.)

25 Opłaty komornicze wynoszą zasadniczo 5\%, 8\% i $15 \%$. Reguluje je art. 49 ust. 1 ustawy o komornikach sądowych i egzekucji

26 Usługę tą zwaną dobrowolną sprzedażą nieruchomości świadczą zwykle pośrednicy w obrocie nieruchomościami.

27 Moga być niekierowane do outsourcingu umowy o zbyt małej lub dużej wartości, kontrakty, w których kredytobiorcy zmarli czy te, w których toczy się postępowanie karne etc.

28 Outsourcing potrafi być cennym źródłem wiedzy na ten temat.

29 Jest to jedna ze standardowych miar windykacyjnych.

30 Art. 509-518 k.c.

31 Art. 38-41 ustawy z dnia 3 lutego 1993 r. o restrukturyzacji finansowej przedsiębiorstw i banków oraz zmianie niektórych ustaw.

32 Art. 92a, 92b oraz art. 104 prawa bankowego.

33 Praktycznie takie obowiązki wierzyciela, jak poinformowanie w siedzibie dłużnika oraz we wszystkich oddziałach banku o sprzedaży jego wierzytelności czynia ustawe o restrukturyzacji finansowej przedsiębiorstw bezużyteczną w przypadku sprzedaży masowych portfeli wierzytelności bądź banków z wieloma oddziałami.
34 Art. 104, ust. 2 pkt. 4 ustawy - Prawo bankowe zwalnia wierzytelności z kategorii ryzyka „stracone" z obowiązku zachowania prawa bankowego, umożliwiając udzielenie w ten sposób informacji niezbędnych do zawarcia i wykonania umów sprzedaży wierzytelności.

35 Sprzedaż długów przez banki wskazywana jest jako alternatywna dla długotrwałego oraz kosztownego ich dochodzenia siłami własnymi, zwłaszcza w kraju, takim jak Włochy o specyficznej kulturze kredytowej oraz mało efektywnym prawnym systemie dochodzenia roszczeń w: Petersson i Wadman (2004).

36 Jednym ze standardowych sposobów radzenia sobie przez banki z problemem wierzytelności niepracujących jest ich sprzedaż niezależnemu podmiotowi windykacyjnemu po cenach rynkowych na co wskazuja Giacomo Calzolari, Giorgio Barba Navaretti, i Alberto Pozzolo (2017).

37 Ustawa z dnia 15 stycznia 2016 r. o podatku od niektórych instytucji finansowych.

38 Należy tutaj wziąć pod uwagę, iż odpis aktualizacyjny dla ekspozycji kredytowych ocenianych metodą grupową może być wyznaczany metodami statystycznymi i rozkładany w całości na wiele lat. Oznacza to, że nawet po dwóch, trzech latach zaległości może być on nie dotworzony w całości. Implikuje to, iż od nie pokrytej odpisem na utratę wartości części należy uiścić podatek bankowy.

39 Do czasu wprowadzenia klauzuli sankcjonującej obejście opodatkowania (nowelizacja Ordynacji podatkowej z 15 lipca 2016 r. - art. 119a ust. 1) w celu sprzedaży wierzytelności stosowana była na rynku struktura prawno-podatkowa w formie spółki komandytowo-akcyjnej, do której bank wnosił w formie aportu wierzytelności będace przedmiotem sprzedaży, a następnie sprzedawał nabywcy cała taką spółkę.

40 Mogą nimi być inwestorzy branżowi/specjalistyczni, a nawet detaliczni. Sameer Join (2012) z banku inwestycyjnego UBS oraz Uniwersytetu Harwarda wskazuje na dwie grupy inwestorów zagranicznych zainteresowanych inwestycjami w tego typu aktywa. Sa nimi inwestorzy specjalizujacy sie w tego typ inwestycjach, tacy jak Distressed Hedge Funds oraz bardziej oportunistycznie podchodzace do inwestycji fundusze Private Equity.

41 Podział taki stosuje się w odniesieniu do klientów indywidualnych oraz od małych i średnich przedsiębiorstw (tzw. MSP), gdyż podejście do klientów korporacyjnych zawsze ma charakter indywidualny bez względu na rodzaj zabezpieczenia.

42 Plik taki nosi nazwę data tape.

43 Wykaz niektórych $\mathrm{z}$ ważnych charakterystyk wykorzystywanych w procesie wyceny wierzytelności jest zawarty w artykułach Pawła Goźlińskiego (2013; 2017). 
44 Przykładowo, dłużnicy w wieku do 20 roku życia i powyżej 60 roku życia charakteryzuja się statystycznie znacznie większym poziomem niewypłacalności od dłużników w wieku 30-40 lat.

45 Statystycznie kobiety są bardziej odpowiedzialne za spłatę swoich zobowiązań od mężczyzn.

46 To trzy ściśle powiązane ze sobą cechy dłużnika, mające duże znaczenie dla wierzyciela. Nie jest niezwykłe, że osoby z wyższym wykształceniem, dobrze płatnym zawodem i wysokimi dochodami będą w większym stopniu skłonne do spłaty zaległości od osób odpowiednio o niskim poziomie wykształcenia, niskopłatnym zawodzie i niskim poziomie zarobków.

47 Zwykle im dłuższy okres zalegania, tym mnie korzystnie wpływa to na prawdopodobną spłatę długu, zwłaszcza biorąc pod uwagę możliwość jego przedawnienia.

48 Od podmiotów, wobec których były podejmowane czynności windykacyjne (np. przez outsourcera), można spodziewać się mniej skutecznego dochodzenia roszczeń niż od podmiotów, wobec których takie działania nie były podejmowane. Dotyczy to w szczególności etapu egzekucji komorniczej.

49 Zwracają na to uwagę Prezes firmy windykacyjnej Ultimo S.A. Anna Gawęska (2014); William Thomas (2010) z US Departament of Tresury oraz Igor Belov i Steven Fleming (2015) z firmy konsultingowej $\mathrm{PwC}$, choć te dwie ostatnie uwagi dotyczą przede wszystkim portfeli wierzytelności korporacyjnych.

50 Już w 2006 roku Julia Gentgen oraz Nico B. Rottke (2008) wspominaja o outsourcingu czy nawet sprzedaży wierzytelności zabezpieczonych hipotecznie jako alternatywie dla wewnętrznego procesu windykacji w niemieckich bankach. Sprzedaż wierzytelności zabezpieczonych hipotecznie w Polsce stała sie w ostatnich kilku latach bardziej popularna jako alternatywa dla banków, które nie moga zaspokoić sie podczas licytacji komorniczych, z których znaczna część kończy się nieskutecznie. Częstym powodem ich nieskuteczności jest zamieszkiwanie przez lokatorów w licytowanym lokalu. W takiej sytuacji bank co prawda może przejąć na księgi, czyl wejść w obowiązki właściciela danej nieruchomości w ciągu 7 dni od terminu nieskuteczne II licytacji (art. 984 k.p.c.). Nie jest to jednak co do zasady praktykowane $\mathrm{z}$ dwóch przyczyn. Po pierwsze administrowanie nieruchomością (opłacenie czynszu, podatków, ubezpieczeń, kosztów napraw etc.), a to jest wymagane po jej przejęciu, nie jest kluczową czynnością, na której powinny się koncentrować banki. Po drugie przejęcie nieruchomości zamieszkałej przez dłużnika może za sobą pociągać konieczność jego eksmisji, czego nie chcą wykonywać bank ze względu na duże ryzyko refutacyjne $\mathrm{z}$ nią związane.
51 Portfele hipoteczne mogą zwykle zawierać od kilkudziesięciu do kilkuset umów kredytowych, podczas gdy portfele wierzytelności masowych mogą liczyć od kilu tysięcy do kilkunastu tysięcy kontraktów.

52 Prezes firmy windykacyjnej Ultimo S.A. Anna Gawęska (2014) zwraca uwage na dużą w warunkach polskich podaż kapitału oraz niestabilne mechanizmy ustalania cen powodujace zawyżenie oraz nieprzewidywalność cen portfeli wierzytelności.

53 Obejmujący wierzytelności zarówno bankowe, jak i niebankowe.

54 Dane pochodza ze zrzeszonych w ramach Konfederacji Przedsiębiorstw Finansowych największych polskich firm windykacyjnych.

\section{Bibliografia}

Anastasiou, D., Louri, H. i Tsionas M. (2016). Determinants of non-performing loans: Evidence from Euro-area countries. Finance Research Letters, 18, 116-119, http://dx.doi.org/10.1016/j. frl.2016.04.008.

Anson, M.J.P., Fabozzi, F.J. i Jones, F.J. (2010). Investing in Distressed Debt, in The Handbook of Traditional and Alternative Investment Vehicles: Investment Characteristics and Strategies. Hoboken, NJ, USA: John Wiley \& Sons, Inc., http:// dx.doi.org/10.1002/9781118258248.ch21.

Bekas-Nowak, M. (2008). Windykacja należności w praktyce. Warszawa: LexisNexis.

Belov, I. i Fleming, S. (2015). Impact of Increasing Distress on Debt Valuation. Referat wygłoszony na konferencji ASA 2015 Advanced Business Valuation Conferemce, Las Vegas.

Calzolari, G., Navaretti, G.B. i Pozzolo, A. (2017) Non-Performing Loans. European Economy Banks, Regulation and The Real Sector, 3(1).

Carpinelli, L., Cascarino, G., Giacomelli, S. i Vacca V. (2016). The management of non-performing loans: a survey among the main Italian banks. Questioni di Economia e Finanza, 311, http://dx.doi. org/10.2139/ssrn.2765373

Constancio, V. (2017). Resolving Europe's NPL burden: challenges and benefits. Keynote speech at an event entitled "Tackling Europe's non-performing crisis: restructuring debt, reviving growth" organized by Breugel Institute, Brussels, 3rd February 2017.

Credit Research Foundation. (1999). Principles and Methods of Collections, https://www.crfonline.org/ orc/cro/cro-5.html, 31.08.2017.

Deville, J. (2015). Lived Economies of Default Consumer Credit, Debt Collection and the Capture of Affect. Oxford: CRESC Culture, Eco- 
nomy and the Social, Routledge, http://dx.doi. org/10.4324/9780203383254.

Deloitte. (2017). "Najważniejsze aspekty opodatkowania rynku sekurytyzacji w Polsce". Materiały konferencyjne, V Kongres Regulacji Prawnych z Obszaru Zarządzania Wierzytelnościami, 25 kwietnia

Enria, A. (2017). The EU banking sector - risks and recovery A single market perspective. London: European Banking Authority.

European Banking Authority. (2016). EBA report on the dynamice and driver sof non-performing exposures in the EU banking sector. London: European Banking Authority.

European Central Bank. (2017). Guidance to banks on non-performing loans. Frankfurt: European Central Bank

Gawęska, A. (2014). Wycena portfela wierzytelności przeterminowanych $z$ perspektywy inwestora. Referat podczas V Bankowego Forum Wierzytelności.

Gentgen, J. i Rottke, N.B. (2008). Workout management of non-performing loans A formal model based on transaction cost economics. Journal of Property Investment \& Finance, 26(1), 59-79, http:// dx.doi.org/10.1108/14635780810845163.

Ghosh, A. (2015). Banking-industry specific and regional determinants of non-performing loans: Evidence from US states. Journal of Financial Stability, 20, 93-104, http://dx.doi.org/10.1016/j. jfs.2015.08.004

Goetz, P. (2004). Asset prices and banking distress: A macroeconomic approach. Bank for International Settlements Working Papers, No. 167, http://dx.doi. org/10.1016/j.jfs.2009.01.001.

Goźliński, P. (2013). Gdy kontrahent zalega z zapłatą należności. Rzeczpospolita, 13 maja.

Goźliński, P. (2017). Wycena portfela wierzytelności przeterminowanych. Pobrano z: http://wycena-przedsiebiorstw.pl/wycena-portfela-wierzytelnosci-rzeterminowanych/ (31.08.2017).

HalabyCooper, R., Read, M. i Ruia, M. (2011). Distressed debt investing. Have we hit rock bottom. London: Edison Investment Research.

Holwek, J. (2006). Negocjacje z dlużnikami Windykacja. Holwek Jarosław, Gliwice: Helion.

International Finance Corporation. (2012). Distressed Asset Transfer Handbook: General Guidelines for the Purchase and Sale of Distressed Assets in the Financial Sector, Washington, http://www. ifc.org/wps/wcm/connect/9e40a3004dcf6f63a784a7ab7d7326c0/DA_Transfer_Handbook_2012. pdf?MOD=AJPERES

Konfederacja Przedsiębiorstw Finansowych. (2016). Giełdy wierzytelności w Polsce Raport z badań - IV kwartat 2016. Gdańsk-Warszawa: Konfederacja Przedsiębiorstw Finansowych.
Konfederacja Przedsiębiorstw Finansowych. (2017). Wielkość polskiego rynku wierzytelności zarzadzanego przez członków KPF, IV kw 2016. Gdańsk: Konfederacja Przedsiębiorstw Finansowych.

Kreczmańska-Gigol, K. (2015). Windykacja polubowna i przymusowa. Proces, rynek, wycena wierzytelności. Warszawa: Difin.

Instytut Badań nad Gospodarką Rynkową. (2010). Rynek zarzadzania wierzytelnościami w Polsce oraz perspektywy jego rozwoju do 2014 roku. Gdańsk: Instytut Badań nad Gospodarką Rynkową.

Join, S. (2012). Investing in Distressed Debt. Alternative Investment Analyst Review (AIAR), 1(2).

Mączyńska, E. (red.). (2017). Ocena poziomu rzeczywistej ochrony praw wierzycieli. Biuletyn Polskiego Towarzystwa Ekonomicznego, 2(77).

Milack, J. Receivables Management and Collection Enforcement. Office of the Information Commissioner of Canada. Pobrano z: https://www. google.pl $/$ url? $\mathrm{sa}=\mathrm{t} \& \mathrm{rct}=\mathrm{j} \& \mathrm{q}=\& \mathrm{esrc}=\mathrm{s} \&$ sourc $\mathrm{e}=$ web $\& \mathrm{~cd}=1 \& \mathrm{cad}=\mathrm{rja} \&$ uact $=8 \& \mathrm{ved}=0 \mathrm{ahU}$ KEwj4geWCpp WAhUMIpoKHbtxCS8QFggpMAA\&url =http $\% 3 \mathrm{~A} \% 2 \mathrm{~F} \% 2 \mathrm{Fwww}$.mthink com $\% 2$ Flegacy $\% 2$ Fwww.revenueproject.com $\% 2 \mathrm{~F}$ content $\% 2$ Fpdf $\% 2$ Ftax 1 wp milack.pdf\&usg $=\mathrm{A}$ FQjCNEWPbN4vZunX03Zx5 5 UbgiO5jZM1pA.

Podel, W. (2014). Windykacja dla wierzycieli, firm windykacyjnych $i$ kancelarii prawnych. Skuteczne Praktyki. Warszawa: Difin.

Petersson, J. i Wadman, I. (2004). Non Performing Loans - The markets of Italy and Sweden. Bachelor Thesis, Uppsala University, Department of Business Studies.

Rozporządzenie Ministra Sprawiedliwości z dnia 22 października 2015 r. w sprawie opłat za czynności radców prawnych (Dz.U. 2015, poz. 1804 z późn. zm.).

Strubel, D. (2015). Źródła i znaczenie informacji w procesie odzyskiwania należności. W: J. Ostaszewski (red.), O nowy ład finansowy w Polsce. Rekomendacje dla animatorów życia gospodarczego (s. 267-277). Warszawa: Oficyna Wydawnicza SGH.

Ustawa z dnia 23 kwietnia 1964 r. - Kodeks cywilny (Dz.U. 1964 Nr 16, poz. 93 z późn. zm.).

Ustawa z dnia 17 listopada 1964 r. - Kodeks postępowania cywilnego (Dz.U. $1964 \mathrm{Nr}$ 43, poz. 296 z późn. zm.).

Ustawa $z$ dnia 27 maja 2004 r. o funduszach inwestycyjnych (Dz.U. Nr 146, poz. 1546 z późn. zm.).

Ustawa z dnia 29 sierpnia 1997 r. o komornikach sądowych i egzekucji (Dz.U. 1997 Nr 133, poz. 882 z późn. zm.).

Ustawa z dnia 28 lipca 2005 r. o kosztach sądowych w sprawach cywilnych (Dz.U. 2005 Nr 167, poz. 1398 z późn. zm.). 
Ustawa z dnia 20 lipca 2001 r o kredycie konsumenckim (Dz.U. 2001 Nr 100, poz. 1081 z późn. zm.).

Ustawa z dnia 12 maja 2011 r. o kredycie konsumenckim (Dz.U. 2011 Nr 126, poz. 715 z późn. zm.).

Ustawa z dnia 29 sierpnia 1997 r. - Ordynacja podatkowa (Dz.U. 1997 Nr 137, poz. 926. z późn. zm.).

Ustawa z dnia 15 stycznia 2016 r. o podatku od niektórych instytucji finansowych (Dz.U. 2016, poz. 68 z późn. zm.).

Ustawa z dnia 15 lutego 1992 r. o podatku dochodowym od osób prawnych (Dz.U. 2011 Nr 21, poz. 397 z późn. zm.).

Ustawa z dnia 6 lipca 1982 r. o radcach prawnych (Dz.U. 1982 Nr 19, poz. 145 z późn. zm.).
Ustawa z dnia 3 lutego 1993 r. o restrukturyzacj finansowej przedsiębiorstw i banków oraz zmianie niektórych ustaw (Dz.U. Nr 18, poz. 82 z późn. zm.).

Ustawa z dnia 29 sierpnia 1997 r. - Prawo bankowe (Dz.U. 1997 Nr 140, poz. 939 z późn. zm.).

Thomas, W. (2010). Loan valuation using present value analysis. Prezentacja. US Department of Treasury, Office of Technical Assistance. Pobrano z: https://www.google.pl/url?sa =t\&rct =j\&q=\&es $\mathrm{rc}=\mathrm{s} \&$ source $=$ web $\& \mathrm{~cd}=1 \& \mathrm{cad}=\mathrm{rja} \&$ uact $=8 \& \mathrm{ve}$ $\mathrm{d}=0$ ahUKEwjw8a-I3vvUAhWLLIAKHdZHDSgQ FggjMAA\&url=http $\% 3 \mathrm{~A} \% 2 \mathrm{~F} \% 2 \mathrm{Fwww}$.ndic.gov. ng $\% 2$ Ffiles $\% 2$ FLoan $\% 2520$ Valuation $\% 2520$ Using\%2520Present \%2520Value\%2520Analysis\%2520-\%2520FDIC.ppt\&usg =AFQjCNF2hkWtnGSCumqiPG-zgyIpRfDU5Q (31.08.2017). 